\title{
Relationship between Manager Selection Practice and Efficiency of Public Service Reform in Transition Countries: The Case Study of Serbia
}

\author{
Borislav Kolarić (Corresponding author) \\ "Telecom Serbia"a.d. Beograd, IJ Sremska Mitrovica \\ 22000, Sremska Mitrovica, Stari Most 6, Serbia \\ Tel: +38-164-6522-411Ｅ-mail: kayak@open.telekom.rs \\ Slobodan Radojčić \\ Municipality of Irig, Irig \\ 22406, Irig, Zmaj Jovina 149, Serbia \\ Tel: +38-164-1861-287 E-mail: borcisoirig@neobee.net
}

Received: January 27, 2011

Accepted: February 23, 2011

doi:10.5430/jms.v2n1p60

\begin{abstract}
Public service reform is a global phenomenon. Increased requirements and pressures made by the users imply finding the adequate form of modernization. Public service transformation aims at providing services in a more effective and efficient way, with enabling a better service providing. In such an environment, manager's role is crucial for the success of public service transformation. The intention of this paper consisted in determining the nature of relations between the way in which the managers are chosen and efficiency of Serbian public services functioning. The presented case study has served us as an illustration of the extent to which existing practice of selecting the managers in public services of Serbia influences the successful reform and functioning of those organizations. Basis of the research sample consisted of th employees in public services in the territory of Srem, one of the regions in Serbia. Basic assumption would be that there is a significant correlation between the existing practice of selecting the managers and successful management within public services and that was proved by this study. Research and analysis of the results obtained have indicated that the current way of selecting managers in public services of Serbia is largely a significant barrier towards the creation of efficient management, capable of creating a better service for the users.
\end{abstract}

Keywords: public services, transformation, leadership, efficient management

\section{Introduction}

Since the end of the 90's, service sector records permanent growth, and service activities are getting an increasing impact on national economies. Thus, during the last decade, the work of public sector has been put into an increasing focus (Pollitt \& Bouckaert, 2004). Liberalization and privatization of public services have set crucial challenge to traditional management in public sector, forcing the yesterday's monopolists to enter the market competition with new private companies. With the success of the new public management, performance targets and increasingly business-oriented approaches to management have obtained a central role in public sector (Osborne \& Gaebler,1992). The same has implied increasing the awareness of public sector performances as a consequence.

Observing the countries in transition and besides the fact that in most cases there is not a real competition and that citizens do not have the alternative in private sector, public services need to be aware of the significance of improving their performances. Due to the increased individualization and emancipation increase, the citizens expect high quality and better efficiency level from public services, as well as greater adaptation to their needs. Such requests to service sector implied the need for a more competitive management and marketing of service organizations (Rootman et al., 2007). That indicates the significance of monitoring the public service performances, observing the inadequacies and elimination of the same. However, apart from many years of attempting the reform of public sector management, the results in the aspect of performance improvement, in most organizations are not entirely convincing. 
Serbia, as one of the countries in transition, is characterized by a lot of heritage from communist and post-communist period, which is also present in the sector of public services. Unlike the developed countries, these organizations are still under the patronage of the state, traditionally hierarchical type of structure with centralized leadership, where the selection of leadership directly depends on party affiliation, or political suitability.

This paper, through empirical research, attempts to determine the nature of the relations between the practice of managers selection and opportunities for improving the functioning of public services in Serbia. By investigating these relations, as well as by identifying the influence of the practice of selecting the managers to the possibility of successful public services reform, especially in context of countries in transition, this paper provides a starting point for debate on management in public services of countries in transition. Therefore, this paper sets the basis for further empirical research concerning the determination of causal relations between the state, political parties and efficient management within public services of countries in transition.

\section{The purpose of research}

Choice and dealing with issues concerning title topic were initiated by current way and quality of service providing by public services in Serbia. The turmoil of transitional period, embodied in instability and poor organization of public services, has not evaded Serbia. Long transitional period was followed by relatively frequent and hasty changes in organizational structure of public services. Public services are non-functional in many segments, which is reflected in insufficiently defined authorities and responsibilities, as well as their overlapping. Within majority of public services, the uniform policy is evident in all organization parts, as well as high level of centralization and lack of the need for adapting to customers' needs. Primary focus is in the function of protecting the integrity of business processes, and not in achieving the results through meeting customers' needs and requirements. Having in mind that it is about the presence of the obsolete type of hierarchical structure with bureaucratic leadership and imposed management „from the top“, the question was to which extent are such persons professional, trained and competent for leadership position in public services.

In recent years, business environment indicates a great interest for human resources necessary for successful organizational transformation. Apart from an increasing need for knowledge workers, much attention is also paid to the transformation of traditional managers into leaders of the new era. That implies the persons who have vision, go ahead, take risks, influence and leadership, who are the initiators of cohesion and good cooperation, and by personal example they encourage and inspire the others in the way that will keep them in the direction of organizational values. Unlike the management, which implies the obligation to achieve organizational goals, the leadership emphasizes interpersonal relationships.

Pursuant to the aforesaid, the research had the aim to determine the level of competence of the set managers and their management style. By examining the employees in public services, it was attempted to reach the information on opinion and attitudes concerning the necessary traits and expertise that the managers need to have for the assigned function and whether they work on improving the work efficiency of public services by their leadership style. Therefore, due to the information obtained, it could be possible to determine the impact of the way of selecting the managers on the successful operation of public services.

\section{Literature review}

One of characteristic of countries in transition is a business environment where operating conditions have significantly changed over the last decade (Setnikar-Cankar, 2006). In recent years, accordance with today's trends and requirements, business environment points out to great interest in human resources that are necessary for a successful organizational transformation (Hung-Wen Lee, 2010). Selden (2007) has argued that all public sector reform initiatives are contingent upon a possessing skilled and talented public servants.

Efficient human resource management has become a key to success. For that reason, the manager's role also changes, and instead of being merely formal plenipotentiaries, they often need to work throughout the organization and within hierarchy (Agranoff \& McGuire, 2003). Managers become the media through which the overall policy, rules, procedures and initiatives of the company are presented to the employees. They, like it or not, need to understand that they have a major role in setting the level of employees' motivation. One of the important characteristics of a successful manager lies in the interest to help the employees in finding the role that matches their talent and expertise. In contrast, bad managers often create destructive tones, which, as the final outcome, undermine the company itself (Buckingham \& Coffman 1999).

Within the organization, people do not work in a vacuum as isolated individuals. They work in complex situations, which include groups, organizational culture, as well as competitive environment (Nollenberger 2006). Today's modern 
trends of management see efficient managers as persons oriented towards strong relationships with employees, always keeping them informed, listening to their ideas and giving them necessary authorizations (Yukl 2006). Efficient managers also practice participatory management, so that the sense of cohesion, personal development and high level of satisfaction between all employees is provided in such organizations. In addition, they provide a clearer picture of orientation and vision in relation to the environment, health mechanisms for innovation and creativity, as well as resources for strengthening organizational culture.

Raelin (2003) claims that leadership represents something that is done by the entire community and where the need for connecting the operations and actions by one operator does not exist. People in the community take leadership role through collective action and management. According to that, Ospina and Folde (2005) see leadership as collective matter, and not as a constituent part of one or more individuals. The community becomes a metaphor for organization. Such organization promotes mutual values. It implies that during the work people commit themselves to communion in which there are common goals towards successful operation of the enterprise and each contribution is valued and recognized and where the voice of each community member is heard (Kouzes \& Posner, 2003).

In addition to that, in developing good relations with employees, the managers need to listen and understand what the employees are talking and experiencing, as well as to give the freedom to employees to express possible dissatisfaction with management decisions (Ivancevich, 2001). In that sense leaders and managers should also learn to use idea generating tools, consensus building tools, effective meeting techniques, and quality improvement tools (Dana 2005). In order to be efficient, these leaders need to have "contextual intelligence", which provides them with great abilities to understand the context in which they live and use current possibilities in the best possible way (Mayo \& Nohria, 2005).

In accordance with the above-mentioned, Nollenberger (2006) points out to the difference between successful leaders and appointed managers. While successful leaders represent a part of the group with the employees that are well-coordinated, the appointed managers are the persons imposed by „higher powers“ and they are exclusively the demonstrators of the position or the power of relationships.

By their studies, Lussier and Achua (2007) prove that the leaders do not have innate characteristics, but they also identify some common characteristics that can be found with all efficient leaders: (1) dominance - that is not mentioned in context of great „,boss“", but in terms of direction and control; (2) high level of energy that drives them to work hard in order to achieve goals; (3) honesty and ethics; (4) belief in oneself; (5) flexibility in terms of adapting to various situations; (6) high degree of empathy in terms of the ability to understand their followers and associates. According to the above-mentioned, Hellriegel, Jackson and Slocum (2002) add one more characteristics of an efficient leader - ability to accept the responsibility for his actions and consequences.

De Vries (2001) ponts out that leadership concept can be observed from two aspects, as an asset and as a process. As an asset, leadership is a set of characteristics - behaviour patterns and personal attributes that make people more efficient in achieving particular goals. As a process, leadership is an attempt of the leader to influence the group members to direct their activities to achieving the common goal by using his own powers and skills. Leaders who manage to change the behaviour of other people, they can have a strong impact not only to their contribution to organization, but also to their attitudes and character (Urlich, Zenger \& Smallwood, 1999).

Effective leaders are often described as „transformational“ leaders. Their practice of delegating authority to other associates influences the development of skills and self-confidence with associates, as well as creation of self-managing teams. By this, all unnecessary controls are eliminated and a strong culture of support to empowering the employees is being built (Yukl 2006).

According to Raelin (2003), Hersey and Blanchard, two dimensions that characterize the nature of leader's followers are suggested: their ability and readiness. They define ability through the elements such as work experience, knowledge they possess and how much capacity do they own to meet the requirements set. Readiness dimension refers to the extent to which the followers are interested in the possibility to assume responsibility, how much they are engaged in work and how much confidence do they have in the aspect of meeting business requirements.

Based on their extensive research, Kouzes and Posner (2002) have identified five practices that are characteristic for the managers of medium and higher level: (1) challenging process, by which leaders search for the opportunity to change status quo, (2) inspiring common vision, (3) enabling the others to act through fostering the cooperation and team building, (4) modelling the way to focus on the behaviour in searching for the goals, (5) encouraging the heart through recognizing the contributions and celebrating the achievements. 


\section{Research methodology}

Presented theoretical frameworks about the significance of efficient management and new approach to human capital management in modern business opposed to that fact that indicates the dissatisfaction of user as a consequence of bad functioning of public services in Serbia is the research goal, generally. It consisted of investigating the existence and nature of impacts that are created by the managers' selection practice to the employees, their motivation and, as ultimate consequence, efficient operation.

Thus conceived, the research goal was focused on two tasks:

- Identifying the level of appointed managers' competence and expertise for the assigned function;

- Determination of managing style that is demonstrated by managers appointed in public services.

By examining the employees and managers in public services in Serbia, it was attempted to make diagnosis of the factors that have relevant impact on the public enterprises' way of doing business, which is not at a very high level according to the large number of users.

\subsection{Sample, research metod and the applied method of statistical analysis of data}

Sample consisted of employees and managers of public services in centres of municipalities in Srem region, and the research has included 186 respondents from 16 public services: public utility company "Komunalac" Irig, public utility company "Komunalac" Indjija, public utility company "Komunalije" Sremska Mitrovica, National park PTT Irig, PTT Stara Pazova, PTT Indjija, public utility company "Vodovod" Ruma, public utility company "Gas" Ruma, public utility company "Vodovod" Sremska Mitrovica, public company "Srem Gas" Sremska Mitrovica, public utility company "Komunalac" Ruma, public company "Vodovod" Sid, PTT Sid, PTT Pecinci, public company "Vodovod" Pecinci.

As the most optimal instrument for relevant research, the questionnaire that consisted of two types of questions was used:

- The first group of questions, based on subjective evaluation of employees and managers, determined their answers and identified the existing conflicts regarding the adequacy, competence and leadership skills of managerial personnel;

- The second group of questions had the task to examine and generate the information related to determination of leadership style that dominates within public services.

Answers in the questionnaire were closed and designed on the basis of Likert scale, so that for each question they gave the respondent a possibility to choose one of five possible answers: "I completely agree"; "I mostly agree"; "I am hesitant"; "I mostly disagree"; "I completely disagree".

Testing the validity of questionnaire as well as the results obtained was realized through several analyses and data processing. Having in mind that it is about categorical data, prior to data processing, there was data scaling so that the following procedures and analysis could be applied afterwards:

- By applying the cluster analysis, the characteristics of answers of two criteria groups - managers and employees were determined.

- MANOVA (multivariate analysis of variance) analysis it was examined whether in the group as a whole there are differences in responses of the two criteria groups observed.

- ANOVA analysis (univariate analysis of variance), differences in responses of the two criteria groups were examined for each question.

- The discriminant analysis of the existing differences obtained in previous analysis is expressed quantitatively, through coefficient of discrimination, which was a prerequisite for the formation of the most frequent responses by relevant issues.

In this paper, the difference by criteria groups of employees in public services and their managers was analyzed. Such results, tested by discriminant analysis and discrimination coefficient, are stronger in comparison to simple testing of questionnaire's reliability because they give an accurate measure of difference and distance of features between criteria groups.

\section{Research results}

As it was mentioned before, the concept of issues contained in questionnaire had the task to generate two types of information that are relevant for the goal and tasks of research. Employees and managers in public services are, on one hand, questioned about their opinions and attitudes regarding the competence, expertise and leadership characteristics of appointed managers, while on the other hand, determining the leadership style within public services was of great importance. The answers obtained were classified into two criteria groups - employees and managers and, as such, they were tested through many types of statistical analysis. The analysis applied had great benefit and application in identifying and determining the difference in responses between two mentioned criteria groups. 


\subsection{Adequacy and competence of selected managerial personnel}

Set of questions, which referred to generating the information regarding adequacy and competence of the management appointed in public services, consisted of 6 questions: "managers in public services are appointed on the basis of political suitability, without adequate knowledge and competence"; "managers in public services are carriers of changes and true leaders"; "managers in public services have a high level of honesty and ethics"; "managers have a high level of empathy"; "managers try to motivate the employees"; "managers inform themselves and deal with problems and difficulties which the employees encounter". These questions were analyzed through the prism of two criteria groups.

By applying cluster analysis, the characteristics of responses of two criteria groups were determined. Multivariate analysis of variance was applied to them for the sake of identifying possible differencies in responses of the two criteria groups as a whole (Table 1.):

$<$ Table 1 about here $>$

By MANOVA analysis, all the questions are viewed as single whole whose aim is to determine whether there are any differences in responses of two criteria groups observed in that whole. This analysis indicates the existence or non-existence of the difference (YES or NO). If the value obtained is less than 0,05 - there is a significant difference; $0,05-0,1-$ there is a difference with an increased risk of existence; and if the result is higher than $0,1-$ there is no statistically significant difference. As the value obtained is within a range between the values 0,05 and 0,1 , i.e. $p=0,06$, it was determined that there is a difference with an increased risk of existence in the answers between two criteria groups.

In order to identify the questions with the determined difference, the univariate analysis of variance was applied, by which each question was separately analyzed, by the same parameters as in case of MANOVA analysis (table 2.):

$<$ Table 2 about here $>$

The data presented in Table 2 indicate that there is difference in responses of employees and managers in case of all six questions. In order to determine size differences in given responses, the discriminant analysis was applied (Table 3. ):

$<$ Table 3 about here $>$

From Table 3, it is observed that the biggest difference in responses exists in opinions regarding managers' ethics (coeff. 0,140 ), as well as the attitudes regarding competence and skills of the managers. On the other hand, greatest similarities in responses between employees and managers are identified on the answers regarding the managers' interest concerning the problems that the employees encounter (coeff. 0,002).

Data and parameters obtained through discrimination coefficient have served as the basis for determining the most frequent responses by the belonging questions in both criteria groups (Table 4.):

$<$ Table 4 about here $>$

Based on the data presented in Table 4, it can be seen that in case of three questions, there are completely different answers, i.e. the biggest difference in opinion between criteria groups. While managers believe that they possess knowledge, competence and ethics and that they represent the carriers of changes in organization, the employees see and experience them in a completely different light. In case of the remaining three questions, the differences in responses are visible, but they are slightly milder in relation to previously mentioned ones.

\subsection{Determination of management style in public services}

Apart from examining the competence and expertise of managerial personnel, it was necessary to conduct a research to determine what management style dominates within public services in Serbia. In order to obtain as precise and detailed information as possible, a group of 8 questions was made and managers and employees, as two criteria groups, provided the answers: "managers influence the employees through formal powers"; "managers strive for cooperation and teamwork";" there is an adequate feedback between employees and managers"; "managers delegate their tasks to employees"; "there is autonomy in decision making in execution of work tasks"; "managers accept suggestions, proposals and critiques made by the employees";"there is a required level of confidence between the employees and managers"; "there is the appropriation of ideas and results of employees by the part of managers".

In this case also, the characteristics of responses of the two criteria groups were determined by the application of cluster analysis. Multivariate analysis of variance was applied to them in order to identify the possible differences in responses of two criteria groups as a whole. (Table 5.):

$<$ Table 5 about here $>$ 
As the obtained result is less than 0,05 , i.e. $p=0,000$, it was determined that there is a significant difference in responses between two criteria groups.

In order to identify the questions in case of which there is a difference determined, the univariate analysis of variance was applied, by which each question was analyzed separately, by the same parameters as in case of MANOVA analysis (Table 6.).

$<$ Table 6 about here $>$

The data shown in Table 6 indicate that there is a difference in responses of employees and managers in all nine questions. In order to determine size differences in given answers, discriminant analysis was applied (Table 7):

$<$ Table 7 about here $>$

From Table 7, it can be seen that the biggest difference in responses exists in opinions regarding the appropriation of idea and results of employees by the part of their managers (coeff. 0,113 ). On the other hand, the greatest similarities in responses of employees and managers are identified in responses regarding the autonomy in employees' decision-making (coeff. 0,003).

Data and parameters obtained through discrimination coefficient served as a basis for determining the most frequent answers by belonging questions in both criteria groups (Table 8.):

$<$ Table 8 about here $>$

Based on the data in Table 8, observing them from the aspect of the two criteria groups, it can be seen that the answers to all 8 questions are in big contrasts. In cases where managers mostly or completely agree, the employees mostly or completely disagree and vice versa.

\section{Discussion}

In accordance with a large number of eminent experts and theorists, transformational leadership and human capital management become significant factors of success in business of an organization, as well as one of the key elements of its competitive advantage. As such, they find their place in basic principles of modern business, regardless of the size or activity of organization.

When it comes to public services of countries in transition, we need to have in mind that they are still, in most cases, state-owned companies that are, apart from bureaucratic administration, characterized by appointing political figures to key management positions. However, we must also consider the requirement of consumers, who wish to be treated and served according to modern marketing principles. Summarizing all data and analyses presented, in the sense of attitudes and opinions of employees in public services and their managers, has enabled the identification of real abilities and competencies of appointed managers, as well as determination of the way, namely style of their managing.

Observing the characteristics of respondents' answers related to competence and expertise of the appointed managerial personnel, managers believe that they are appointed to that position due to their knowledge and competence, that they have a high level of ethics, honesty and empathy. Therefore, they possess the required leadership competencies, which enable them to be the carriers of changes towards more efficient work of public services. In those efforts, they are able to motivate the employees, as well as to permanently deal with their problems that emerge during the realization of business processes. In short, managers see themselves as adequate and competent persons, ready and capable to deal with challenges of modern marketing environment.

In contrast, the employees see their managers as imposed persons who have earned their position on the basis of political agreements. When it comes to competence, the employees believe that their managers do not have the necessary knowledge, abilities and skills that are required by their position. In addition, the employees believe that managers do not have a sincere desire to change bureaucratic and centralized business systems, because the existing organizational structure suits them in many aspects. Therefore, they do not have the energy necessary to motivate their employees, nor do they have a lot of sense for them. The way in which they reached the position, as well as the inconsistency between the values they proclaim and what they demonstrate in practice gives them the epithet of non-ethics and dishonesty from the part of employees.

Attempt to determine management style that is present in public services of Serbia has once again provided opposing opinions and attitudes of managers in relation to employees. On this issue, managers see themselves as persons who do not reach very much for formal sources of power in order to affect the employees. On the contrary, they consider that they strive for cooperation and teamwork, and thus there is a good two-way communication, on the basis of which they receive and accept critiques, suggestions and proposals from the employees. If follows that the confidence level between them and employees is at the satisfactory level, which results in delegating the tasks to employees and providing necessary autonomy for realization of the same. 
On the other hand, the employees experience their managers as persons that are preoccupied by themselves and preservation of appointed function, who are not fit to the position of leader for the creation of organizational changes, who base their „expertise“ on formal powers. For those reasons, they maintain relationships with employees on strictly hierarchical principles, without the possibility of giving the autonomy in work, with noticeable absence of will for delegating the responsibilities and authorizations to their associates. In their management, the absence of cooperation and support to teamwork is noticeable. In addition, they are inclined to appropriate the ideas or good results of employees and present them as their successful achievements, by which they largely lose in authority credibility, confidence and ethics. They are not benevolent at criticism by the employees, nor they are interested in their proposals and suggestions, which indicates poor vertical communication, i.e. the absence of the necessary „feedback“. In short, the employees see their managers as authoritarian figures that hide their poor knowledge and competence behind strictly hierarchical relationships with employees.

Having in mind that all above-mentioned attitudes and opinions of employees regarding their managers are supported by large dissatisfaction of users in the aspect of public services' work, the honesty of managers' answers in relation to subjective evaluation of their abilities, skills and competences is doubted.

In the light of current trends of public services reform in transitional countries, bureaucratic structure cannot be efficient any longer. Operations management must be clearly separated from the government so neither politicians nor government bureaucrats can interfere in day-to-day operational decisions. Changes and processes of the reform do not have access through traditional, authoritarian and bureaucratic methods anymore. On the contrary, they require to be supported through knowledge and expertise, but also through well-set vision and mission, teamwork building, participation and authorization of employees in all key elements. These processes require the leaders and managers that will be able, with the employees, to plan and direct the course of organization towards the successful operation. For that reason, public services reforms need to be focused on debureaucratization and decentralization that need to follow the generation of new approach to management, openness, participation, flexibility and understanding.

Even with the awareness of new trends existence in the market, changing users' requirements, as well as increasing emphasis on transition from classical human resource management to managing through development, training, cooperation, participation, authorization and motivation of employees, management of public services in Serbia has not done much regarding this issue. The results presented point out to the fact that obsolete type of hierarchical structure with bureaucratic managing and imposed management „from the top“ are not adequate elements of organizational design of public services that would be able to meet users needs and desires, which as a result implies an insufficient level of service performances and users dissatisfaction.

All the above-mentioned points out to the need for transformation of bureaucratic organizations, creation of organizational structure with minimal hierarchy and introduction of professional "leadership" management. By abandoning all previous patterns and practice of appointing ,political“ managers without proved abilities, knowledge and skills and by creation of possibility for the persons who have the required competencies and characteristics of true leaders to apply for their positions, the first step towards professional "leadership" management would be made. In case of such persons, apart from competence and orientation to efficient fulfilment of business goals, the existence of orientation to employees, i.e. motivation for cooperation with employees in the sense of two-way communication, participation, giving the autonomy and delegating the responsibility, would also be implied. Thus, a favourable climate of confidence and open cooperation between managers and employees would be created, which would result in satisfaction with business and motivation of employees, as well as their acceptance of managers as true leaders. All the above-mentioned would contribute to more efficient business and better service providing by public services, which would ultimately result in increasing the level of users' satisfaction.

\section{Conclusion}

The purpose of this paper consisted of determining the nature of relationship between the practice of appointing the managers and efficiency of public services functioning in transitional countries. The presented case study has served us as an illustration of the extent to which existing practice of selecting the managers in public services of Serbia influences the successful reform and functioning of those organizations. Results and analysis of the research have indicated that the current way of selecting managers in public services of Serbia is largely a significant barrier towards the creation of efficient management, capable of creating a better service for the users.

The obsolete type of hierarchical structure with imposed management and bureaucratic administration are not the elements that will support the public services reform for the sake of efficient operation and improving the performances for meeting customers' needs and desires. 
In the effort to create an organization of high performances, the selection of managers must not be of political nature, but it has to be based on expertise, knowledge and leadership competencies of personality. In addition, the leaders must be ready for the new type of cooperation with employees. With good two-way communication, providing sufficient autonomy and delegating the responsibility, the managers will allow the employees to participate in collective leadership. Thus, a new door is opened for sincere cooperation, knowledge exchange, building of confidence and satisfaction with work, by which the performances of public services will largely be increased.

The results obtained can be considered a starting point in planning successful transformation, and opinions and attitudes of employees as necessary assistance in establishing adequate organizational design in public services of Serbia. Therefore, this paper need to be observed as a basis for further empirical research regarding the determination of causal relationships between the state, political parties and efficient management within public services of transitional countries.

\section{References}

Agranoff, R., \& McGuire, M. (2003). Collaborative Public Management. Washington DC: Georgetown University Press. Buckingham, M., \& Coffman, C. (1999). It's the Manager, Stupid. Fortune, October 25, pp. 366-368.

Dana, B. (2005). Developing a Quality Management System: The Foundation for Performance Eexcellence in Long Term Care. Washington DC: AHCA.

De Vries, M.K. (2001). The Leadership Mystique: A Users Manual for the Human Enterprise. London, Prentice Hall.

Hellriegel, D., Jackson, S.E., \& Slocum, J.W. (2002). Management: A Competency Based Approach. South-Western.

Hung-Wen, Lee (2010). Maximizing Knowledge Preservation and Transformation in Organization. African Journal of Business Management 4 (17), pp. 3769-3774.

Ivancevich, J.M. (2001). International Human Resource Management, 8nd Eds. New York: McGraw-Hill/Irwin.

Kouzes, J. M., \& Posner, B. Z. (2002). The leadership challenge, 3nd Eds. San Francisco: Jossey-Bass.

Kouzes, J.M., \& Posner, B.Z. (2003). Credibily: How Leaders Gain and Lose it, Why People Demand it. San Francisco: Jossey-Bass.

Lussier, R.N., \& Achua, C.F. (2007). Effective Leadership. Thomson South Western.

Mayo, A. J., \& Nohria, N. (2005). Zeitgeist Leadership. Harvard Business Review. October. pp. 45-60.

Nollenberger, K. (2006). Combining Leadership \& Management Skills. Government Finance Review, Avgust, pp. 29-32.

Osborne, D., \& Gaebler, T. (1992). Reinventing Government: How the Entrepreneurial Spirit is Transforming the Public Sector. New York: Penguin Press.

Ospina, S., \& Folde, E. (2005). Towards a Framework of Social Change Leadership. Paper presented at the Annual Meeting of the Public Management Research Association. September 2005, Los Angeles.

Pollitt, C., \& Bouckaert, G.. (2004). Public Management Reform. A Comparative Analysis. New York: Oxford University Press Inc.

Raelin, J.A. (2003). Creating Leaderful Organization: How to Bring out Leadership in Everone. San Francisco: Berrett-Koehler Publishers, Inc.

Rootman, C., Tait, M., \& Bosch, J. (2007). The Influence of Bank Employees on Bank Customer Relationship Management, Acta Commercii, pp.181-182.

Selden Coleman, S. (2007). Innovations and Global Trends in Human Resource Management Practices, in B. G. Peters \& J.Pierre (Eds.), The Handbook of Public Administration (pp. 39-49). London: Sage.

Setnikar-Cankar, S. (2006). Transition Countries and New Public Management:The Case of Slovenia, International Business \& Economics Research Journal,5 (8), pp. 45-54.

Urlich, D., Zenger, J., \& Smallwood, N. (1999). How Leaders Build the Business and Improve the Botom Line. Boston: Harward Business School Press.

Yukl, G.. (2006). Leadership in Organizations. Upper Saddle River, NJ: Prentice-Hall. 
Table 1. A level of distinction in opinions between two criteria groups

\begin{tabular}{|l|c|c|c|}
\hline & $\mathbf{n}$ & $\mathbf{F}$ & $\mathbf{p}$ \\
\hline MANOVA & 5 & 4.948 & 0.00 \\
\hline
\end{tabular}

Table 2. A level of distinction in opinions between two criteria groups by the questions asked

\begin{tabular}{|l|c|c|c|c|}
\hline & $\chi$ & $\mathrm{R}$ & $\mathrm{F}$ & $\mathrm{p}$ \\
\hline $\begin{array}{l}\text { Managers in public services are set on the basis of political } \\
\text { suitability, without adequate knowledge and competence }\end{array}$ & 0.315 & 0.331 & 10.987 & 0.000 \\
\hline $\begin{array}{l}\text { Managers in public services are the carriers of changes and } \\
\text { true leaders }\end{array}$ & 0.358 & 0.383 & 15.304 & 0.000 \\
\hline $\begin{array}{l}\text { Managers in public services have a high level of honesty and } \\
\text { ethics }\end{array}$ & 0.341 & 0.363 & 13.472 & 0.000 \\
\hline Managers have a high level of empathy & 0.229 & 0.235 & 5.204 & 0.025 \\
\hline Managers try to motivate the employees & 0.347 & 0.370 & 14.129 & 0.000 \\
\hline $\begin{array}{l}\text { Managers inform themselves and deal with problems and } \\
\text { difficulties which the employees encounter }\end{array}$ & 0.316 & 0.334 & 11.147 & 0.001 \\
\hline
\end{tabular}

Table 3. Coefficient of difference in opinions between two criteria groups by the questions asked

\begin{tabular}{|l|c|}
\hline & Discrimination coefficient \\
\hline Managers in public services have a high level of honesty and ethics & 0.140 \\
\hline Managers in public services are carriers of changes and true leaders & 0.121 \\
\hline $\begin{array}{l}\text { Managers in public services are set on the basis of political suitability, } \\
\text { without adequate knowledge and competence }\end{array}$ & 0.118 \\
\hline Managers try to motivate the employees & 0.039 \\
\hline Managers have a high level of empathy & 0.037 \\
\hline $\begin{array}{l}\text { Managers inform themselves and deal with problems and difficulties } \\
\text { which the employees encounter }\end{array}$ & 0.002 \\
\hline
\end{tabular}

Table 4. Difference of characteristic in opinions between respondents by two criteria groups

\begin{tabular}{|l|c|l|l|}
\hline & $\begin{array}{c}\text { Dicr. } \\
\text { coeff. }\end{array}$ & managers & employees \\
\hline $\begin{array}{l}\text { Managers in public services have a high } \\
\text { level of honesty and ethics }\end{array}$ & 0.140 & I completely agree & I completely disagree \\
\hline $\begin{array}{l}\text { Managers in public services are carriers of } \\
\text { changes and true leaders }\end{array}$ & 0.121 & I completely agree & I completely disagree \\
\hline $\begin{array}{l}\text { Managers in public services are set on the } \\
\text { basis of political suitability, without } \\
\text { adequate knowledge and competence }\end{array}$ & 0.118 & I completely disagree & I completely agree \\
\hline Managers try to motivate the employees & 0.039 & I mostly agree & I completely disagree \\
\hline Managers have a high level of empathy & 0.037 & I mostly agree & I mostly disagree \\
\hline $\begin{array}{l}\text { Managers inform themselves and deal with } \\
\text { problems and difficulties which the } \\
\text { employees encounter }\end{array}$ & 0.002 & I mostly agree & I mostly disagree \\
\hline
\end{tabular}

Table 5. A level of distinction in opinions between two criteria groups

\begin{tabular}{|c|c|c|c|}
\hline & $\mathrm{n}$ & $\mathrm{F}$ & $\mathbf{p}$ \\
\hline MANOVA & 7 & 4.448 & 0.000 \\
\hline
\end{tabular}


Table 6. A level of distinction in opinions between two criteria groups by the questions asked

\begin{tabular}{|l|c|c|c|c|}
\hline & $\chi$ & $\mathrm{R}$ & $\mathrm{F}$ & $\mathrm{p}$ \\
\hline managers influence the employees through formal powers & 0.223 & 0.229 & 4.924 & 0.029 \\
\hline managers strive for cooperation and teamwork & 0.219 & 0.224 & 4.704 & 0.033 \\
\hline there is an adequate feedback between employees and managers & 0.230 & 0.237 & 5.285 & 0.024 \\
\hline managers delegate their tasks to employees & 0.199 & 0.203 & 3.817 & 0.054 \\
\hline there is autonomy in decision making in execution of work tasks & 0.211 & 0.215 & 4.331 & 0.040 \\
\hline $\begin{array}{l}\text { managers accept suggestions, proposals and critiques made by } \\
\text { the employees }\end{array}$ & 0.274 & 0.285 & 7.857 & 0.006 \\
\hline $\begin{array}{l}\text { there is a required level of confidence between the employees and } \\
\text { managers }\end{array}$ & 0.361 & 0.387 & 15.70 & 0.000 \\
\hline $\begin{array}{l}\text { there is the appropriation of ideas and results of employees by the } \\
\text { part of managers }\end{array}$ & 0.299 & 0.313 & 9.672 & 0.003 \\
\hline
\end{tabular}

Table 7. Coefficient of difference in opinions between two criteria groups by the questions asked

\begin{tabular}{|l|c|}
\hline & $\begin{array}{c}\text { discrimination } \\
\text { coefficient }\end{array}$ \\
\hline there is the appropriation of ideas and results of employees by the part of managers & 0.113 \\
\hline there is a required level of confidence between the employees and managers & 0.069 \\
\hline there is an adequate feedback between employees and managers & 0.058 \\
\hline managers influence the employees through formal powers & 0.037 \\
\hline managers strive for cooperation and teamwork & 0.030 \\
\hline managers delegate their tasks to employees & 0.024 \\
\hline managers accept suggestions, proposals and critiques made by the employees & 0.007 \\
\hline there is autonomy in decision making in execution of work tasks & 0.003 \\
\hline
\end{tabular}

Table 8. Difference of characteristic in opinions between respondents by two criteria groups

\begin{tabular}{|l|c|l|l|}
\hline & $\begin{array}{c}\text { Dicr. } \\
\text { coeff. }\end{array}$ & managers & employees \\
\hline $\begin{array}{l}\text { there is the appropriation of ideas and } \\
\text { results of employees by the part of } \\
\text { managers }\end{array}$ & 0.113 & I completely disagree & I completely agree \\
\hline $\begin{array}{l}\text { there is a required level of confidence } \\
\text { between the employees and managers }\end{array}$ & 0.069 & I mostly agree & I completely disagree \\
\hline $\begin{array}{l}\text { there is an adequate feedback between } \\
\text { employees and managers }\end{array}$ & 0.058 & I mostly agree & I completely disagree \\
\hline $\begin{array}{l}\text { managers influence the employees } \\
\text { through formal powers }\end{array}$ & 0.037 & I mostly disagree & I completely agree \\
\hline $\begin{array}{l}\text { managers strive for cooperation and } \\
\text { teamwork }\end{array}$ & 0.030 & I mostly agree & I completely disagree \\
\hline $\begin{array}{l}\text { managers delegate their tasks to } \\
\text { employees }\end{array}$ & 0.024 & I mostly agree & I completely disagree \\
\hline $\begin{array}{l}\text { managers accept suggestions, proposals } \\
\text { and critiques made by the employees }\end{array}$ & 0.007 & I mostly agree & I mostly disagree \\
\hline $\begin{array}{l}\text { there is autonomy in decision making in } \\
\text { execution of work tasks }\end{array}$ & 0.003 & I mostly agree & I mostly disagree \\
\hline
\end{tabular}

